\title{
MARITAL PROPERTY AND THE CONFLICT OF LAWS: THE CONSTITUTIONALITY OF THE "QUASI- COMMUNITY PROPERTY" LEGISLATION
}

Addison v. Addison ${ }^{1}$ upholds the constitutionality of those sections of the 1961 quasi-community property legislation which reclassify common law marital property into community property for purposes of divorce; ${ }^{2}$ in addition, it apphies these sections to personal property brought to California prior to $1961 .^{3}$ Addison therefore stands as a denial of the universality of the two general conflict of laws principles that marital property interests ${ }^{4}$ of a husband and wife in personal property are governed by the laws of the domicile of acquisition, ${ }^{5}$ and that any law

162 Cal. 2d 558, 399 P.2d 897, 43 Cal. Rptr. 97 (1965).

2 Section 140.5 of the Civil Code defines "quasi-community property" as:

all personal property wherever situated and all real property situated in this State heretofore or hereafter acquired:

(a) By either spouse while domiciled elsewhere which would have been community property of the husband and wife had the spouse acquiring the property been domiciled in this State at the time of its acquisition; or

(b) In exchange for real or personal property, wherever situated, aequired other than by gift, devise, bequest or descent by either spouse during the marriage while domiciled elsewhere.

Under the 1961 amendment to $\S 146$ of the Civil Code, quasi-community property is divided between the spouses on divorce or separate maintenance in the same manner as community property. See generally, Schreter (now Kay), "Quasi-Community Property" in the Conflict of Laws, 50 CAITF. L. REV. 206 (1962).

3 The marital property in question was traceable to personalty the spouses had brought with them to California in 1949. How much, if any, of such property was acquired by the husband before marriage was not clear however. This issue is to be retried. $62 \mathrm{Cal} .2 \mathrm{~d}$ at 569 570, 399 P.2d at 904, 43 Cal. Rptr. at 104.

4 "Marital property interests" refer to those interests which one spouse has in the property acquired by the other spouse solely because of the marriage relationship existing between them (but excluding the expectancy of inheriting upon the death intestate of the other). See Marsh, Martrax Property In Conflict of Laws 11 (1952). The term refers to what has been elsewhere denominated "inter vivos marital property rights." See, e.g., 3 CatrFORNIA LAW REviston CONOA'N, REPORTS, Reconomandations \& StudIES I-1 to I-35 (1961).

5 The first general conflict of Inws principle-that marital property interests of a husband and wife in personal property are governed by the laws of the domicile of acquisition-rests on the traditional conflict of laws doctrine of "vested rights." See BEALE, Summary of the Conflict of Laws, in 3 Cases on the Confict of LAws 501, 515-17 (1900). This view is the theoretical basis of the first Restatement of Conficts. See RESTatement, Confuicr of Laws $\$ \S 290-93$ (1934); 2 BEALE, A Treatise oN THE Conflict of Laws \$§ 292.1-293.2 (1935). See also note 15 infra.

The vested rights theory, however, has come under increasing attack. See generally Cavers, $A$ Critique of the Choice-of-Law Problem, 47 Harv. L. Rev. 173 (1933) i Cook, The Logical and Legal Bases of the Confict of Laws, 33 YaLE L.J. 457 (1924). The "state's interest" rationale in Addison exemplifies a changing approach to conflict of laws problems, which emphasizes the freedom of the forum state to dispose of controversies before it on the basis of its own notions of justice. See text accompanying notes 52-56 infra. But see RESTATEMENT (SECOND), Confeict of LaWs $\$ \$ 290,293$ (Tent. Draft No. 5, 1958). 
changing inter vivos Inarital property rights $^{\mathfrak{b}}$ can apply prospectively only.

These two principles, the first dealing with a territorial or spatial conflict and the second dealing with a temporal conflict, have governed Cahfornia marital property law for more than half a century. While Addison constitutes a limitation on these two principles, it does not overrule Estate of Thornton ${ }^{8}$ and Spreckels v. Spreckels ${ }^{9}$ which enunciated these principles as constitutional axioms. ${ }^{10}$ The question is, therefore, the effect, if any, that Spreckels and Thornton will have on the successful implementation of the quasi-community property legislation and on future changes in the community property law. As will be demonstrated, the failure to overrule the entire constitutional theory underlying Thornton raises serious questions as to the constitutionality both of the homestead sections of the 1961 quasi-community property legislation ${ }^{11}$ and of further legislation which will be necessary to prevent the circumvention of the divorce sections of the quasi-community property legislation.

\section{I}

\section{STATUTORY ATTEMPTS TO CHANGE THE "DOMICILE OF ACQUISITION" PRINCIPLE}

California is the only state which has attempted by legislation to change the "domicile of acquisition" principle." The principle has been summarized by the Supreme Court of California: "[M]arital property rights in personalty or choses in action acquired by a spouse are deter-

6 See note 4 supra.

7 This principle is not uniformly recognized throughout the United States. While it has become an axiom of California marital property law, see note 27 infra, it has been rejeeted in other community property states. See, e.g., Arnett v. Reade, 220 U.S. 311 (1911) (New Mexico); Warburton v. White, 176 U.S. 484 (1900) (Washington). See also Comment, 20 CAIIF. L. Rev. 201, 202 (1932).

81 Cal. 2d 1, 33 P.2d 1 (1934).

${ }^{9} 116$ Cal. 339, 48 Pac. 228 (1897).

10 Professor Kay in her article on the quasi-commumity property legislation concludes that hopefully the 1961 legislation, in a "proper" case, will inspire reexamination of Thornton and Spreckels and "result in the prospective overruling of Spreckels and the consequent elimination of even the sbadow of Thornton. The way will then be clear for the legislature to establish a single marital property law for all Californians." Schreter, supra note 2, at 244.

A unitary marital property system for all Californians would be one in which only one classificatory scheme is applied to all property of California domiciliaries regardless of where or when the property was acquired. In other words, it would be one which reclassifies property acquired elsewhere and applies any changes in laws governing inter vivos rights of liusbands and wives to all existing marital property.

11 Cat. Crv. Code $\$ \S 1237.5,1238,1265$.

12 Marser, op. cit. supra note 4, at 209; Note, 10 CacrF. L. Rev. 154, 155 (1922). 
mined under the laws of the domicile of the acquiring spouse"; ${ }^{18}$ they "are not lost simply because property is transported into another state and exchanged there for other property."14 The basic purpose of this principle is to protect the expectations of all those persons who may have interests in the marital property under the laws of the domicile of acquisition. ${ }^{15}$ These expectations are protected when the courts of the new domicile classify the marital property the sane way it was classified under the laws of the old dormicile, and then apply the appropriate laws of the old domicile. A correct application of this "vested rights" principle to a case involving a couple bringing movables to California from a common law state should therefore result in the marital property laws of the former domicile determining the rights and interests of the spouses in the property. Due to the equivocality" of the term "separate property," lowever, the California courts have consistently misapphed this principle. $^{17}$

California courts classify the marital property according to the laws of the domicile of acquisition, but then apply California law governing

\footnotetext{
13 Schecter v. Superior Court, 49 Cal. 2d 3, 10, 314 P.2d 10, 14 (1957). See also Rozan v. Rozan, 49 Cal. 2d 322, 326, 317 P.2d 11, 12-13 (1957).

14 Tomaier v. Tomaier, 23 Cal. 2d 754, 759, 146 P.2d 905, 908 (1944).

15 The "domicile of acquisition" principle is based on the "territorial" theory of conflict of laws. "The traditional theory of territoriality . . . largely eliminates the uncertainty of the local law theory, by treating rights as vested by their proper applicable laws and enforcing those rights no matter in what forum they are asserted." Horowitz, Conflict of Law Problems in Community Property, 11 WASH. I. REv. 121, 125 (1936); see note 5 supra.
}

16 "Things are said to be named 'equivocally' when, though they have a common name, the definition corresponding with the name differs for each. ... On the other hand, things are said to be named 'univocally' which have both the name and the definition answering to the name in common." Aristotie, Categortae 1-8 (McKeon ed. 1941). The mistake of the California courts has been to treat "separate property" as if it were a univocal term.

There is a similar terminological problem with respect to spouses bringing personal property from one commumity property state into California in so far as community property has different incidents of ownership in the former domicile. See Kay, Conflict of Laws: Foreign Law as Datum, 53 CAJTF. I. REv. 47, 52 (1965). For example, in Texas the rents and profits of separate property belong to the community, Arnold v. Leonard, 114 Tex. 535, 273 S.W. 799 (1925), whereas in California the rents and profits of the separate property of a married person are partially classified as community property. California allocates rents and profits between separate and community property on the basis of the time and effort devoted by the acquiring spouse in augmenting the rents and profits. See, e.g., Estate of Neilson, 57 Cal. 2d 733, 371 P.2d 745, 22 Cal. Rptr. 1 (1962); Gilmore v. Gilmore, 45 Cal. 2d 142, 287 P.2d 769 (1955); Pereira v. Pereira, 156 Cal. 1, 103 Pac. 488 (1909); Van Camp v. Van Camp, 53 Cal. App. 17, 199 Pac. 885 (1921). This problent exists on a much smaller scale than that created by the equivocality of the tern "separate property" and has not received the attention of the California courts.

17 Leflar, Community Property and Conflict of Laws, 21 CarrF. L. REv. 221, 226-27 (1933). See also Abel, Barry, Halsted \& Marsl, Rights of a Surviving Spouse in Property Acquired by a Decedent While Domiciled Outside California, 47 CaxIF. L. REv, 211, 212 (1959). 
that class of property. ${ }^{18}$ This failure to consider that property acquired by persons in a common law state, whether before or after marriage, has different marital property characteristics than any property acquired by a husband or wife while domiciled in Califormia ${ }^{19}$ results in the courts applying neither the law of the common law state of acquisition nor the law of California. ${ }^{20}$ The nonacquiring spouse is thus denied the protection of both marital property systems. The purposes of both the principle itself and the marital property laws of the two conflicting systems are therefore defeated ${ }^{21}$ unless application of the principle is made pursuant to an understanding of the equivocal nature of the tern "separate property."22 When a married person moves to California with property which would be his separate property under the laws of his former common law domicile, application of the domicile of acquisition principle should not, therefore, result in that property being treated in the same way as the separate property acquired by a married person while domiciled in California is treated.

Cahifornia has made two legislative attempts to change the domicile of acquisition principle. The first was an attempted nullification; the second only a himitation. In 1917 section 164 of the Civil Code was amended to include within the definition of community property all real property situated in California and personal property wherever situated that would have been community property had it been acquired by a married person while domiciled in California..$^{23}$ Estate of Frees ${ }^{24}$ construed the amendment as applying prospectively only. In 1923, by in-

18 See, e.g., Latterner v. Latterner, 121 Cal. App. 298, 302, 8 P.2d 870, 872 (1932); note 38 infra.

19 MARSE, op. cit. supra note 4 , at 226.

20 Abel, Barry, Halsted \& Marsh, supra note 17, at 213.

21 Ieflar, supra note 17 , at 227.

22 The incidents of separate property ownership in California are in many respects different from those of common law property ownership. In the common law jurisdictions both husband and wife have valuable property rights in the separate property of the other, for example, the wife's right of dower or the wife's right to set aside a conveyance "in fraud of" her marital rights. Abel, Barry, Halsted \& Marsh, supra note 17, at 212, 221. From the viewpoint of the California marital property system, therefore, this form of ownership is a hybrid, sharing features of commumity and California separate property. In MARSH, op. cit. supra note 4 , at $23 \%$, the Cahifornia courts are urged to recognize the fact of a third form of ownership and to apply the laws governing the marital interests in such property "in such a manner that will most nearly effectuate the apparent legislative pohicy."

For a detailed listing of the various marital property rights which the nonacquiring spouse has in common law property, California (or civil law) separate property, and community property, see $i d$. at $27-67$.

23 Cal. Stats, 1917, ch. 581, at 827.

24 187 Cal. 150, 201 Pac. 112 (1921). The decision was based on the general rule of statutory construction that retroactive appication should be given only when it is clear that such is the legislative intent, and the provision of $\$ 3$ of the California Civil Code that "no part of it is retroactive, unless expressly so declared." Id. at 155, 201 Pac. at 114. 
serting the words "heretofore or hereafter,"25 the legislature expressed its intention to have the 1917 amendment apply retroactively. This attempt was held to be unconstitutional in Estate of Drishaus. ${ }^{20}$ The basis of the decision was the principle enunciated in 1897 in Spreckels $v$. Spreckels, ${ }^{27}$ and followed by the California courts for more than sixty years, that to apply legislation decreasing the dominion and control of the husband over existing community property is to unconstitutionally deprive the husband of a vested right. Finally, Estate of Thornton, ${ }^{28}$ which involved property brought to Cahifornia in 1919, held that the 1917 amendment, whether applied retroactively or not, was itself unconstitutional. ${ }^{29}$

Although the constitutional theory underlying Thornton and Spreckels has been judicially questioned ${ }^{30}$ and strongly protested by commentators, ${ }^{31}$ any legislative attempt to treat property acquired by a married person while domiciled elsewhere as community property ${ }^{32}$ or to alter retrospectively the inter vivos marital property rights of spouses seemed futile after Thornton. The two general principles of conflict of laws, that marital property interests must be governed by the laws of the place and

25 Cal. Stats. 1923, ch. 360, at 746.

26199 Cal. 369, 249 Pac. 515 (1926).

27116 Cal. 339, 349, 48 Pac. 228, 231 (1897). This principle has become an axiom in California marital property law and is referred to as the second general conflict of laws principle. See note 7 supra and accompanying text.

281 Cal. 2 d 1, 33 P.2d 1 (1934).

29 See In re Miller, 31 Cal. 2d 191, 196, 187 P.2d '22, 724-25 (1947).

30 Justice (now Chief Justice) Traynor, in Boyd v. Oser, 23 Cal. 2d 613, 623, 145 P.2d 312, 318 (1944) (concurring opimion), stated: "The decisions that existing statutes changing the rights of husbands and wives in community property can have no retroactive application have become a rule of property in this state and should not now be overruled. It is my opinion, however, that the constitutional theory on which they are based is unsound. . . . That theory has now become a rule of property and should not invalidate future legislation in this field intended by the Legislature to operate retroactively."

${ }^{31}$ See, e.g., Arnstrong, "Prospective" Application of Changes in Commumity Property Control-Rule of Property or Constitutional Necessity?, 33 CALIF. L. Rev. 476, 482, 495, 501-05 (1945); Comment, 15 CALIF. L. Rev. 399, 406-07 (1927).

${ }^{32}$ Section 201.5 of the Probate Code, passed a year after the Thornton decision, reclassified conmon law marital property into conmunity property for purposes of intestate succession by the nonacquiring spouse. It was upheld as constitutional on the grounds that it was a succession statute and that inheritance rights are purely statutory. In re Miller, 31 Cal. 2d 191, 187 P.2d 722 (1947). The concern of this Comment, however, is with inter vivos nuarital property rights.

In the 1958 case of Paley v. Bank of Anterica, 159 Cal. App. 2d 500, 324 P.2d 35 (1958), the court reiterated the unconstitutionality of any attenipt to reclassify inter vivos marital property rights on the basis of Spreckels and Thornton, and held invalid an attenpted interpretation of $\S 201.5$ of the Probate Code which would have given the former nondomiciliary wife testamentary power over half the marital property acquired by her hushand while domiciled elsewhere. For a criticisn of the case see Leflar, Conflict of Laws, 35 N.Y.U.L. Rev. 62, 92 (1960). See also, Ehrenzweic, Conflict of Laws $\$ 245$ (1962). 
time of acquisition, had attained the status of constitutional axioms in Califorma marital property law.

In 1961 the California legislature again attempted, but in a much more limited way, to change the status of marital property acquired by husbands and wives while domiciled elsewhere so as to give them some of the incidents of ownership they would have had if the property had been acquired in California. This was intended to act as a substitute for the marital property rights which the spouses would lose as a result of the California courts' classification as separate property under Califorma law all marital property acquired elsewhere. Under the 1961 "quasicommunity property" legislation, ${ }^{33}$ common law marital property which would have been community property had it been acquired in California is treated as community property for three specific purposes: (1) disposition of the marital property in case of divorce or separate maintenance; (2) declaration of a homestead durmg the lifetime of the spouse who acquired the property; and (3) assessment of gift taxes. ${ }^{34}$ For all other purposes common law marital property is treated as the California separate property of the acquiring spouse. Hence the notion of "quasicommunity property."

\section{II}

THE RECLASSIFICATION OF COMMON LAW PROPERTY INTO COMMUNITY PROPERTY FOR PURPOSES OF DIVORCE

Prior to 1961 the wife could not, on obtaming a separate maintenance or divorce decree, secure any interest in her husband's marital acquisitions if they were made in a common law state or traceable to acquisitions in a comnion law state. ${ }^{35}$ This was the result of California's misapplication of the principle that a mere change in domicile could not alter marital interests in property. "Given their decision that the wife did not "own" any of her husband's personal property acquired in a common law state, ${ }^{37}$ the California courts disposed of the marital property involved in a divorce or separate inaintenance action not according to the law of the

33 Cal. Stats. 1961, ch. 636, at 1838. The legislation makes changes in the following California code sections: California Civil Code $\$ \S 140.5,140.7,1237.5$ (new), 141, 142, 143, 146, 148, 149, 164, 176, 1238, 1265 (amended); California Probate Code $\$ \S 201.5,661,663$ (amended); California Revenue and Taxation Code $\$ \S 13672,15300,15302.5$ (new), 15301, 15306 (amended).

34 Catifornia Continung Educatton of the Bar, Review of Selected 1961 Code Legistation 643, 673 (1961); 3 CALIFoRnIa LAW Reviston Comar's, Reports, ReconMENDATTONS \& STUDIES I-1, I-6 (1961).

85 Schreter, supra note 2 , at 207-08.

${ }^{30}$ See, e.g., Kraemer v. Kraemer, 52 Cal. 302, 305-06 (1877).

87 See Estate of O'Connor, 218 Cal. 518, 526, 23 P.2d 1031, 1034 (1933). 
former domicile, but according to the rules pertaining to California separate property. ${ }^{38}$ The courts did not consider it relevant that the wife would have had a one-half undivided interest in the marital property and been entitled to a disposition under section 146 of the Civil Code had the property been acquired in California by the husband.80

Section 146 of the Civil Code, ${ }^{40}$ as amended in 1961, allows the court, on a decree of divorce or separate maintenance, to dispose of quasicommunity property in the same way it does community property. Addison upholds the constitutionahity of this section-and of section 140.5 which defines "quasi-community property"41 -in the face of Spreckels and Thornton without expressly overruling them. Yet under the rule of Thornton, sections 140.5 and 146 of the Civil Code would be unconstitutional if they change the status of marital property, thereby divesing the acquiring spouse of vested rights, merely because of a change of domicile by the spouses. The court in Addison deals with the holding of Thornton by: first, in effect overruling two of the three constitutional bases underlying Thornton; ${ }^{42}$ and second, by distinguishing the legislation involved in Thornton from the quasi-community property legislation involved in Addison. ${ }^{43}$

Justice Peters, citing Justice Traynor's concurring opinion in Boyd v. Oser ${ }^{44}$ and the commentaries attacking the vested rights principle of

88 In California, as discussed above, see text accompanying note 18 supra, the courts classify the property involved according to the law of the domicile of acquisition and then apply California law governing the California category of marital property with the same name. Therefore, if the property involved is the husband's separate property, the result is the wife is given nothing-not even what she would have been entitled to under the laws of the, domicile of acquisition. See Latterner v. Latterner, 121 Cal. App. 298, 302, 8 P.2d 870, 872 (1932); Marsh, A Study Relating to Inter Vivos Rights in Property Acquired by Spouse

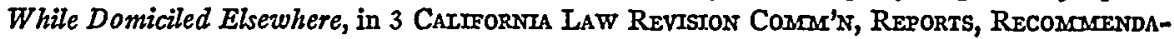
TIONS \& STUDIES I-21, I-32 (1961).

30 "The Legislature has not granted authority for an award of separate property, or an interest therein in lieu of support ..., either in an action for divorce or for separate maintenance." Jenkins v. Jenkins, 110 Cal. App. 2d 663, 665, 243 P.2d 79, 81 (1952); see Fox v. Fox, 18 Cal. 2d 645, 117 P.2d 325 (1941); Tremper v. Tremper, 39 Cal. App. 62, 177 Pac. 868 (1918).

40 Under \& 146 of the California Civil Code, when the decree of separate maintenance or divorce is based on adultery, incurable insanity, or extreme cruelty, the community property is divided between the spouses as the court deems just. If the decree is rendered on any other ground, the community property is divided equally between the parties.

${ }^{41}$ See note 2 supra. For the argument that the only difference between $\S 140.5$ and the 1917 amendment to $\$ 164$ of the Civil Code is one of terminology, and the conclusion that $\$ 140.5$ must therefore be declared unconstitutional under Thornton, see Answering Brief in the District Court of Appeal for Respondent, pp. 16-17, Addison v. Addison, 62 Cal. 2d 558, 399 P.2d 897, 43 Cal. Rptr. 97 (1965).

$4262 \mathrm{Cal}$. 2d at 564, 566, 568, 399 P.2d at 901-03, 43 Cal. Rptr. at 101-03.

48 Id. at 566, 568, 399 P.2d at 901-03, 43 Cal. Rptr. at 101-03.

4423 Cal. 2d 613, 623, 145 P.2d 312, 318 (1944); see note 30 supra. 
Spreckels, ${ }^{45}$ says that "the correctness of the rule of Thornton is open to challenge."146 The rule of Thornton is based on three constitutional arguments: (1) Legislation which attempts to reclassify separate property acquired by a spouse in a common law state as community property, based only on the act of bringing the property into the community property state and establishing a domicile there, takes the property of the acquiring spouse without due process of law in violation of the fourteenth amendment; (2) such legislation denies the husband coming to California from a common law state the same protection of his vested rights as the California husband is given and thus abridges his privileges and immunities under section 2 of article IV of the Constitution of the United States; and (3) such legislation denies the husband coming from a common law state the right to become a California domiciliary without having his vested property rights impaired, thereby violating the privileges and immunities clause of the fourteenth amendment. ${ }^{47}$

Arguments (1) and (2) are overcome in Addison by applying a "balancing of interests" rationale and resorting to the police power of the state to impair vested rights when it is reasonably necessary to insure the public welfare. ${ }^{48}$ Argument (3) is avoided by distinguishing former section 164 of the Civil Code held to be unconstitutional in Thornton from the new quasi-community property legislation. ${ }^{49}$

\section{A. The "Due Process" Argument}

Argument (1)-Thornton's due process argument-is the same as the rationale underlying Spreckels, "which established, by a concession of counsel, that changes in the community property system which affected 'vested rights' could not constitutionally be applied retroactively . . . ."50 The theory of Spreckels was that when a spouse acquired property, all rights in that property given hin by the law of his domicile vested in him. ${ }^{51}$ Any legislation that impaired a vested marital property right, as,

$45 \mathrm{See}$, e.g., commentaries cited in note 31 supra.

46 Addison v. Addison, 62 Cal. 2d 558, 565-66, 399 P.2d 897, 901, 43 Cal. Rptr. 97, 101 (1965).

47 See Comment, 15 CAITF. L. REv. 399, 406 (1927). The arguments presented there by now Justice Peters as to the unconstitutionality of the 1917 amendment to $\$ 164$ of the Civil Code constituted a prediction of the rule enunciated in Thornton. The opinion in Thornton, however, fails to distinguish the two privileges and inmunities arguments. Instead it confuses them: Argument (2) is based on the fourteenth amendment, see note 58 infra; argument (3) is not articulated, and no mention is made of article IV, $\$ 2$ of the Federal Constitution at all.

4862 Cal. 2d at 566, 568-69, 399 P.2d at 902-03, 43 Cal. Rptr. at 102-03.

48 Id. at 568, 399 P.2d at 903, 43 Cal. Rptr. at 103.

60 Id. at 565, 399 P.2d at 901, 43 Cal. Rptr. at 101.

51116 Cal. 339, 348-49, 48 Pac. 228, 231 (1897). 
for example, by decreasing the husband's, and thereby simultaneously increasing the wife's, control over the existing community property, constituted a taking of property without due process of law. Since reclassifying common law marital property into community property on a change of domicile would also result in decreasing the husband's interest in the marital property, any legislative attempt to do so, such as the 1917 amendment to section 164 of the Civil Code, would be unconstitutional under the Spreckels axiom. Given this California rule of marital property rights, the court in Thornton declared that "to take the property of $A$ and transfer it to $B$ because of his citizenship is also to take his property without due process of law." ${ }^{2} 2$

Professor Kay criticizes this argument on the ground that it overlooks that the $A$ and $B$ involved are necessarily husband and wife, and that $A$ 's property is not being handed over to $B$, but rather $B$ is being given rights in $A$ 's property according to the community property system as a substitute for the common law rights which $B$ lost when $A$ and $B$ became California domiciliaries. ${ }^{53}$

The court in Addison points out the substantial interest of California, the current domicile of the parties to the divorce, in the disposition of the marital property on the dissolution of the marriage. ${ }^{54}$ Quoting Professor Armstrong's "pohice power-State's interest" argunent against the vested rights axiom of Spreckels, ${ }^{55}$ Justice Peters declares that this is a case where it is reasonably necessary for the public welfare that "vested" property riglits be impaired. Hence, giving the wife that portion of the quasi-community property which the court deems equitable under section 146 of the Civil Code does not constitute a taking of the husband's property without due process of law. A reasonable nieans to promote the

521 Cal. 2d 1, 5, 33 P.2d 1, 5 (1934).

53 Schreter (now Kay), "Quasi-Community Property" in the Conflict of Laws, 50 CaLrF. L. Rev. 206, 218-19 (1962).

64 62 Cal. 2d at 567, 399 P.2d at 902, 43 Cal. Rptr. at 102. Unfortunately Justice Peters found it necessary to use moralistic language to emphasize the substantiality of the interest. "In the case at bar it was Leona who was granted a divorce from Morton on the ground of the latter's adultery and hence it is the spouse guilty of the marital infidelity from whom the otherwise separate property is sought by the operation of the quasi-community property legislation. We are of the opinion that where the innocent party would otherwise be Ieft unprotected the state las a very substantial interest and one sufficient to provide for a fair and equitable distribution of the nuarital property without running afoul of the due process clause of the Fourteenth Amendment." Id. at 567, 399 P.2d at 903, 43 Cal. Rptr. at 103. One wonders whether Justice Peters' language would have been less fervent in a typical, agreed upon "extreme cruelty" case where the lusband was contesting nothing but the application of $\S \S 140.5$ and 146 of the Civil Code. Certainly Justice Peters' argument runs counter to the noodern trend in both legislation and social thinking to eradicate the concept of moral fault from the settlements of divorce. See Schreter, supra note 53, at 237-38.

55 See Armstrong, supra note 31. 
state's interest in the protection of wives moving from common law states on dissolution of their marriage in California has been devised by the legislature. The resulting loss of property rights by the acquiring spouse when the quasi-community property legislation is applied is less severe in terms of the consequences for the public well-being than has been the application of Thornton. The quasi-community property legislation does not, therefore, constitute a denial of due process to the acquiring spouse. ${ }^{56}$

\section{B. The First "Privileges and Immunities" Argument}

Argument (2) above-that the quasi-community property legislation is unconstitutional under the privileges and immunities clause of section 2 of article IV of the United States Constitution ${ }^{57}$-is overcome in Addison by a similar balancing of interests rationale. The Thornton argument is, in essence, that since under the rule of Spreckels, the legislature cannot change the marital property laws to affect existing property rights of California citizens, California would discriminate against noncitizens by asserting the power to reclassify their nuarital property rights. ${ }^{58}$ Justice Peters might have attacked the Thornton premise by overruling or limiting Spreckels and held that nuarital property riglits of California citizens may be disturbed when reasonably necessary to promote a matter of legitimate state concern; ${ }^{50}$ having so held, the quasi-community property legislation could not have been said to discriminate against spouses coming into California from common law jurisdictions. Justice Peters chose instead to leave the Spreckels rule intact and to deny the absolute nature of the privileges and immunities clause. ${ }^{60}$

The privileges and immunities clause, Justice Peters observes, bars

5062 Cal. 2d at 566-67, 399 P.2d at 902, 43 Cal. Rptr. at 102.

57 U.S. Const. art. IV, \& 2: "The Citizens of each State shall be entitled to all Privileges and Immunities of Citizens in the several States."

88 The court in Thornton reasoned thus: "So long as we are bound by the holding that to limit the right of one spouse by increasing the right of the other in property acquired by their united labors is the disturbance of a vested right, we entertain no doubt of the application of at least two provisions of the 14th amendment .... If the right of a husband, a citizen of California, as to his separate property, is a vested one and may not be impaired or taken by California law, then to disturb in the same manner the same property right of a citizen of another state, who chances to transfer his domicile to this state, bringing his property with him, is clearly to abridge the privileges and immunities of the citizen." I Cal. $2 \mathrm{~d}$ at 5,33 P.2d at 5.

69 See notes 84-85 infra and accompanying text for the argument that Spreckels has been overruled by Addison.

60 By failing to deny the axiomatic nature of the Spreckels rule, Justice Peters implicitly admits that the quasi-community property legislation denies some of the privileges and immunities enjoyed by a California spouse to those spouses coming into California with property acquired in common law jurisdictions. Perhaps he ought frankly to have conceded this. 
only discriminatory treatment of citizens from other states when there is no substantial reason for it. ${ }^{.1}$ Given independent reasons for the disparity of treatment, the inquiry in each case is "whether such reasons do exist and whether the degree of discrimination bears a close relation to them." ${ }^{\prime \prime 2}$

In Addison and similar cases to which the divorce aspects of the quasicommunity property legislation apply, there are ample reasons for this disparity of treatment. The wife in such a case, as a former nondomiciliary, is a member of a class of persons who lost the protection which would have been afforded by her former domicile had she sought a divorce there before inoving to California. She is therefore in need of protection by the new domicile state. This the 1961 amendment to section 146 of the Civil Code purports to give. "Hence, the discrimination, if there be such, is reasonable and not of the type article IV of the Federal Constitution seeks to enjoin."

The problem with the court's rationalization is that it is questionable whether it is reasonable to treat the former nondomiciliary husband and the California husband differently vis-à-vis the deprivation of their "vested" rights. There is no explanation offered in the Addison opinion as to how the court can maintain that it is reasonable to deprive a former nondomiciliary of his "vested" rights in order to protect his wife on dissolution of their marriage in California while at the same time, at least implicitly, maintaining that it is not reasonable to deprive a California husband of his "vested" rights by retroactively applying changes in the community property laws designed to give his wife needed protection. The interests being balanced in the two cases are the same: the husband's interest in maintaining intact his rights in the marital property as opposed to society's interest in seeing that the wife's rights in the marital property are sufficient for her protection. Why the balance should be weighted in the wife's favor when it is a reclassification problem as in Addison, but should be weighted in the husband's favor when it is a retroactivity problem as in Spreckels, is at best unclear.

\section{The Second "Privileges and Inmunities" Argument}

Argument (3), the remaining basis of Thornton, is that to reclassify marital property because of a change of domicile is to deny the former nondomiciliary, who acquired the marital property, the privileges and

6162 Cal. 2d at 568, 399 P.2d at 903, 43 Cal. Rptr. at 103. See also McGowan v. Maryland, 366 U.S. 420 (1961); Toomer v. Witsell, 334 U.S. 385 (1948); Snowden v. Hughes, 321 U.S. 1, 8 (1943).

6262 Cal. 2d at 568-69, 399 P.2d at 903, 43 Cal. Rptr. at 103.

B3 Ibid. 
immunities guaranteed him by the fourteenth amendment to the United States Constitution. The privileges and imnunities protected by the fourteenth amendment are those granted to citizens of the United States as distinct from citizens of the several States. ${ }^{64}$ While Justice Peters exphicitly recognizes this ${ }^{65}$ he fails to make the following kind of argument against the validity of the remaining basis of Thornton. The former nondomiciliary is not being unconstitutionally denied any privileges and immunities if he does not have a constitutionally guaranteed right to retain all the marital property rights he acquired under the laws of his former domicile. If he is not necessarily suffering a loss of property without due process of law, a right one has as a United States citizen, when his marital property interests are diminished on a change of domicile, as Addison holds he is not, then what federally created right is he being denied the privilege of retaiming? To say simply that he has such a right which caunot be impaired without abridging the privileges and immunities guaranteed by the fourteenth anjendment is to beg the question.

Instead of attacking the second Thornton privileges and immunities argument, Justice Peters avoids the issue by distinguishing the legislation involved in Thornton from that involved in Addison. While "Thornton may be read as holding that the legislation there in question impinged. upon the riglit of a citizen of the United States to maintain a domicile in any state of his choosing without the loss of valuable property rights," ${ }^{\prime 68}$ and thus constituted a violation of the privileges and immuni-

64 Hamilton v. Regents of the University of Cal., 293 U.S. 245, 261 (1934); Twining v. New Jersey, 211 U.S. 78, 94-97 (1908). The privileges and immunities clause of the fourteenth amendment "has not as yet assumed large significance in constitutional law, in part because of the difficulties of giving workable contours to the provision and in part because of the growing and overlapping role of the 'equal protection' and 'due process' clauses which were jonied with it in Section 1 of the Fourteenth Amendment." BarRETr, Bruton \& Honnotd, Constitutionat Law 595 (2d ed. 1963). See also LockHart, Kaymsar \& Choper, Constitutional Law 378 (1964).

In commenting on the meaning of the phrase "privileges and immunities of citizens of the United States" as used in the fourteenth amendment, the Supreme Court in Twining held that, "Privileges and immunities of citizens of the United States, . . . are only such as arise out of the nature and essential character of the national government, or are specifically granted or secured to all citizens or persons by the Constitution of the United States. ... Thus among the rights and privileges of national citizenship recognized by this court are the right to pass freely from state to state; ... the right to petition Congress for a redress of grievances; ... the right to vote for National officers; ... the right to enter public lands; ... the right to be protected against violence while in the lawful custody of a United States marshal; ... and the right to inform the United States authorities of violation of its laws." 211 U.S. at 97.

${ }^{65} 62$ Cal. 2d at 568, 399 P.2d at 903, 43 Cal. Rptr. at 103.

60 Ibid. 
ties clause of the fourteenth amendment, "the quasi-community property [divorce] legislation does not cause a loss of valuable rights through change of domicile." ${ }^{167}$ The legislation involved in Thornton purported to convert quasi-community property into community property for all purposes. ${ }^{68}$ The acquiring spouse's rights with respect to the quasi-community property were therefore curtailed merely by crossing the boundary into California. The divorce sections of the quasi-community property legislation, on the other hand, do not reclassify marital property of spouses who become Cahifornia domiciliaries unless they seek divorce or separate maintenance. ${ }^{69}$ Therefore, if the spouses do not seek legal alteration of their marital status after moving to California, the legislation involved in Addison, as opposed to that involved in Thornton,

67 Ibid.

68 Calffornia. Continudng Edtcation of the Barl, op. cit. supta note 34 , at 643,675 .

69 "The legislation under discussion, unlike old section 164, makes no attempt to alter property rights merely upon crossing the boundary into California. . . . Instead, the concept of quasi-commumity property is applicable only if a divorce or separate maintenance action is filed here after the parties have become domiciled in California. Thus, the concept is applicable only if, after acquisition of domicile in this state, certain acts or events occur which give rise to an action for divorce or separate maintenance. These acts or events are not necessarily connected with a change of domicile at all." 62 Cal. 2d at 566, 399 P.2d at 901-02, $43 \mathrm{Cal}$. Rptr. at 101-02. Note the apparent requirement of domicile of both partics that Justice Peters is reading into $\$ 146$ of the Civil Code. For problems in not restricting the 1961 amendinent of $\S 146$ to California domiciliaries, see Schreter, supra note 53, at 228-35. The significance of these problems has been increased by the recent holding of the California Supreme Court that domicile is neither sufficient nor necessary for jurisdiction in an action for separate maintenance. Goodwine v. Superior Court, 63 A.C. 503, 407 P.2d 1, 47 Cal. Rptr. 201 (1965). "An action for separate maintenance is essentially an action for support ...., seeking a money judgment against the defendant. Jurisdiction does not depend on domicile but on acquirmg personal jurisdiction over the husband or quasi-in-rem jurisdiction over his property. ... Once quasi-in-renl jurisdiction is established, the court can award a money judgment to the extent of the defendant's interest in the property attached." Id. at 505 .

The argument that the state has an interest in its domiciliarics and the marital property disposition on termination of their marriage, used to uphold the constitutionality of the divorce sections of the quasi-community property legislation in Addison, would not be applicable in the case of a nondomiciliary wife seeking relief vis-ż-vis her nondomiciliary husband's quasi-community property in a separate naintenance action. The 1961 amendment to $\S 146$ of the Civil Code requires, however, that quasi-community property be disposed of as comnumity property in separate maintenance actions. Whether the constitutionality of the quasi-community property separate maintenance sections as applied to nondomiciliaries will be upheld is questionable. It cannot be upheld on the basis of the Addison rationale. That its application may be limited to California domiciliaries is suggested by the following qualifications in Goodwine: "Exercising jurisdiction in these cases does not encourage forumshopping, since the court will not necessarily apply the substantive law of the forum under the applicable conflict of laws rules. . . . In determining the applicability of the doctrine [of forum non conveniens asserted by the defendant husband], the court must consider the public interest as well as the private interests of the litigants. The court must consider such factors as ... the burden on the community in litigating matters not of local concern, and the desirability of litigating local matters in local courts. Id. at 506-07. 
has no effect on their respective rights in the marital property they acquired in their old domicile.

Perhaps the explanation for Justice Peters' failure to attack the third argument underlying Thornton, as he did the first two, is that this argument, like the axiom of Spreckels, has become a "rule of property" in California. ${ }^{\text {70 }}$ As recently as 1958 one finds such statements as, "[O]ur Legislature camıot constitutionally exact as the price of residence here that plaiutiff give up vested rights in property which he acquired and which he owned before he came here." argued, citing Thornton, is to abridge the "privileges and immunities of a citizen of the United States." ${ }^{\prime 72}$ In other words, this third basis of Thornton has, like the rule of Spreckels, become an axiom of California marital property law which, unlike the first two constitutional bases of Thornton, Addison refuses to disturb.

Given Addison's holding that marital property rights acquired in a common law jurisdiction can be disturbed on the dissolution of the nuarriage after the spouses have become California domiciliaries, the question is: Using the balancing of interests rationale of Addison, will this holding be extended to uphold legislation which, for other specified purposes, affects marital property rights of spouses during their marriage? Addison constitutes a limitation on the principle that marital property interests of husband and wife must be governed by the laws of the domicile of acquisition. This limitation is justified by the clear "interest of the state of the current domicile in the matrimonial property of the parties [which] is substantial upon the dissolution of the marriage relationship."73 Further limitations can be justified similarly, especially given California's recognition of "the public interest in the institution of marriage." ${ }^{4}$ As will be argued below, ${ }^{75}$ such an extension of Addison is necessary in order to prevent circumvention of the purposes of the quasi-comnlunity property legislation.

70 See note 30 supra.

71 Paley v. Bank of America, 159 Cal. App. 2d 500, 509, 324 P.2d 35, 41 (1958); Leflar, Conflict of Laws, 34 N.Y.U.L. REv. 20, 43 (1959).

72 Paley v. Bank of America, supra note 71, at 508, 324 P.2d at 41. "The real problem . . . is whether the State of California can lay down as a condition of residence that any person who wants to become domiciled here must consent in advance to the application of the community property laws of this state to all personal property that he brings with hino." Conment, 15 CALrF. L. REv. 399, 406 (1927). For the classical formulation of the concept of "consent" utilized in the above quotation, see PLATO, CRITO (Library of Liberal Arts 2d ed. 1956).

73 Addison v. Addison, 62 Cal. 2d 558, 567, 399 P.2d 897, 902, 43 Cal. Rptr. 97, 102 (1965).

74 DeBurgh v. DeBurgh, 39 Cal. 2d 858, 863, 250 P.2d 598, 601 (1952).

75 See text accompanying notes 86-120 infra. 


\section{III}

\section{Addison AND THE RETROACTIVE APPLICATION OF LEGISLATION}

\section{CHANGING INTER VIVOS MARITAL PROPERTY RIGHTS}

The second principle of inter vivos marital property rights, ${ }^{70}$ which has become axiomatic in California under the doctrine of Spreckels, ${ }^{77}$ is that legislation altering the respective rights of husband and wife in the unarital property can be applied prospectively only. In other words, when there is a conflict of laws in time, the law which governed the marital property at the time of acquisition, as opposed to any new laws which now govern that type of property (laws of the present time), is the law which must be presently applied to determine the respective rights of the spouses. To do otherwise is, under the Spreckels axiom, to unconstitutionally disturb a vested right.

According to Professor Kay, "the 1961 amendment, by virtue of its application to property acquired 'heretofore or hereafter,' will reopen in a proper case the question of the legislature's constitutional power to disturb vested property rights by retroactive legislation." Addison case the marital property in question was traceable to personalty the spouses had brought with thein to California in $1949 .{ }^{70}$ Under the California law of 1949 this property would have been treated as the husband's separate property under the laws of Illinois, the domicile of acquisition. Therefore, section 146 of the Civil Code would not have applied. However, after the 1961 amendment to section 146, that section is applicable, assuming that the property in question would have been community property had it been acquired in Cahfornia. The court, in holding that the quasi-community property legislation could constitutionally be applied to the Addisons' marital property, for the first time sanctioned the retroactive application of legislation changing inter vivos

76 See note 7 supra. Note that the conflict here is a temporal one, rather than territorial. The question is not whether the law of domicile $I$ or domicile II should be applied in determining the classification of the marital property, but whether the law of domicile II at time $A$ or time $B$ pertaining to the classification of the property in question should be applied.

77 See notes 7, 27 supra and accompanying text.

78 Schreter, supra note 53, at 214; see CAL. CIv. Code \$ 140.5; note 2 supra.

70 As far as the retroactivity issue is concerned, the crucial time point, when considering which California law is apphicable to marital property acquired while domiciled elsewhere, is the time of change of domicile. When considering which law is to apply to marital property acquired while the spouses are California domiciliaries, the analogous crucial time point is the time of acquisition. Under the Spreckels axiom, changes in the commumity property laws can be apphed only to property acquired after the new law and not traceable to property acquired before. Therefore, applying Spreckels, it follows that changes in the law governing marital property rights in property acquired elsewhere can be applied only to spouses who became domiciled in California after the legislative change. 
marital property rights. Unfortunately, the court refrained altogether from directly discussing the retroactivity issue. Instead it side-stepped the issue by remarking that the statute was not being applied retroactively because "the legislation here involved neither creates nor alters rights except upon divorce or separate maintenance. The judgment of divorce was granted after the effective date of the legislation."

Under the Spreckels axiom, the 1949 Califorma law respecting spouses' rights in marital property acquired elsewhere should have controlled in Addison. Instead, the court applied present law governing the disposition of quasi-community property on divorce. From this result it would seem to follow that changes in the community property laws can now be retroactively applied to California domiciliaries. But Addison did not expressly overrule Spreckels.

The court in Addison emphasizes that it is altering marital property rights only for the purposes of divorce. ${ }^{81}$ The quasi-community property legislation does not affect the husband's rights in the marital property during the continuance of the marriage relationship as did the legislation confined to prospective application by Spreckels. ${ }^{82}$ The legislation that is given retroactive effect in Addison is therefore distinguishable from more general community property legislation which the commentators have so strongly argued should be given retroactive effect. ${ }^{83}$ Interestingly enough, however, Justice Peters, in upholding the constitutionality of the divorce sections of the quasi-community property legislation, uses the same basic argument used in urging prospective overruling of the Spreckels axiom. That argument is based on the state's police power to diminish rights to use and dispose of property "with due process" when reasonably necessary for the public welfare. ${ }^{84}$ Given the acceptance of

8062 Cal. 2 d at 569,399 P.2d at 904,43 Cal. Rptr. at 104.

81 The limited purpose of the quasi-community property legislation was also stressed by the Law Revision Commission, especially in rendering its opinion that it will not be held unconstitutional under Thornton. 3 CALIFORNIA LAw REviston COMEM'N, REPORTS, RECOMMENDATIONS \& STUDIES, I-1, I-7-I-8 (1961). This was also the main point relied on by plaintiff's attorney in Addison. Opening Brief in the District Court of Appeal for Appellant, p. 16; Petition for Hearing in the Supreme Court of the State of California for Appellant, pp. 18, 22. This was also the respondent's attorney's main point of contention. Answering Brief in the District Court of Appeal for Respondent, pp. 16-17; Petition of Morton Cutler Addison for Relrearing in the Supreme Court of the State of California, p. 12.

82 The 1891 amendment to $\$ 172$ of the Civil Code, involved in Spreckels, gave the wife the power to invalidate a gift of the commumity personal property made by the liusband without her consent. Cal. Stats. 1891, ch. 220, at 425.

83 See Armstrong, supra note 31; Comment, 27 Carrr. L. Rev. 49, 50-52 (1938) (Professor Arnistrong's argument in summary form).

84 "As Professor Armstrong has correctly pointed out ... 'Vested rights, of course, may be impaired "with due process of law" under many circumstances. The state's inherent sovereign power includes the so called "police power" right to interfere with vested property 
this argument in Addison as the basis for disturbing-for limited purposes-marital property rights acquired while domiciled elsewhere, the door is open for the acceptance of this type of argument in a similar case where marital property rights acquired in Cahifornia are disturbed by an attempted retroactive application of changes in the community property system.

A more sophisticated and direct approach to the conclusion that, given Addison, changes in the community property laws can now be applied retroactively is based on the postulate that "retroactivity and reclassification present the same constitutional question under the due process clause." ${ }^{\prime 85}$ If property rights can be disturbed by applying community property concepts to property acquired in a common law jurisdiction, then property rights can similarly be disturbed by retroactive application of a statute changing the inter vivos rights of spouses in community property. The basis of this argument is the following: When community property concepts are applied to common law marital property, the spouses' respective rights in that property are different than they were when the property was acquired and subsequently brought into Cahfornia. Some of the rights belonging to one spouse under the common law system of marital property are transferred to the other spouse at the point of reclassification. Precisely the same thing happens when changes in the community property laws are applied retroactively to California husbands and wives. The marital property interests of each spouse in the existing community property are redefined on application of new community property statutes. If it does not violate the due process clause of the fourteenth amendment to alter the balance of marital property rights existing between husband and wife by reclassifying their marital property, then it would not violate the due process clause to alter the balance of marital property rights existing between California husbands and wives by bringing their marital (community) property under new community property laws.

In more general terms, the conclusion is: Addison upholds the constitutionality of hiting the principle that marital property interests of a husband and wife nust be governed by the laws of the domicile of acquisition. Addison thus implicitly upholds the constitutionality of limiting the principle that marital property interests of a husband and

rights whenever reasonably necessary to the protection of the health, safety, morals, and general well being of the people. . . The constitutional question, on principle, therefore, would seem to be, not whether a vested right is impaired by a marital property law change, but whether such a change reasonably could be believed to be sufficiently necessary to the public welfare as to justify the impairment." $62 \mathrm{Cal}$. $2 \mathrm{~d}$ at 566, 399 P.2d at 902, 43 Cal. Rptr. at 102 .

85 Schreter, supra note 53 , at 217 . 
wife must be governed by the laws existing at the time of acquisition. Addison should therefore be construed as implicitly constituting a prospective overruling of Spreckels.

IV

AddisOn'S REFUSAL TO OVERRULE THORNTON AND THE FATE OF THE "QUASI-COMMUNITY PROPERTY" LEGISLATION

While Addison eliminates the first two constitutional arguments underlying Thornton, which are founded on the Spreckels axiom of vested rights, the third basis of Thornton-which stands independently of Spreckels-is not disturbed. ${ }^{86}$ In other words, only two-thirds of the constitutional theory underlying Thornton is undermined by Addison. The remaming one-third was not an insurmountable obstacle in Addison because the court was able to distinguish section 146 of the Civil Code, as amended in 1961, from the legislation involved in Thornton, in terms of its time of application and its effect on the respective marital property rights of husband and wife during the continuance of the marriage relationship; ${ }^{87}$ however, the court's failure to overrule the entire constitutional theory underlying Thornton will raise serious questions as to the constitutionality of the homestead sections of the 1961 quasi-community property legislation, and may permit circumvention of the purpose of the divorce sections of the 1961 legislation.

\section{A. The Constitutionality of the Homestead Sections of the Quasi-Community Property Legislation}

Especially interesting here is that the former nondomiciliary wife, rather than the husband, ${ }^{88}$ will claim that section 1237.5 and the 1961 amendment to section 1238 of the Civil $\mathrm{Code}^{89}$ are unconstitutional

\footnotetext{
${ }^{86}$ See text accompanying notes 49,72 supra.

${ }^{87}$ See note 69 supra and accompanying text.

88 The only loss to the husband under the homestead quasi-community property legislation is a non-inter vivos right suffered by his estate after his death. Prior to 1961 if the wife declared a homestead on her husband's separate real property without his consent, the property did not vest in her on his death. Under the 1961 amendment to $\S 663$ of the Probate Code, if the former nondomiciliary husband's common law realty would have been community property had it been acquired by a California husband, this property passes to his wife on his death if she has declared a homestead on it during his lifetime-with or without his consent. This reclassification of rights is like that achieved under $\S 201.5$ of the Probate Code, which has been held constitutional. See note 32 supra.

89 Section 1237.5 of the Civil Code defines quasi-community property for purposes of $\S \S 1238-42$. Section 1238 allows the claimant, if he or she is married, to select the homestead: "(a) From the community property; or (b) From the quasi-community property; or (c) From the separate property of the husband; or (d) Subject to the provisions of Section 1239 , from the property held by the spouses as tenants in 'common or in joint tenancy or from the separate property of the wife."
} 
under Thornton. Sle will be able to argue that these sections, unlike the divorce aspects of the quasi-community property legislation involved in Addison, cannot be distinguished from the legislation involved in Thornton in terms of the time of application and the impact on the spouses' respective marital property rights during the continuation of the marriage relationship.

Prior to 1961 either spouse could, under section 1238 of the Civil Code, declare a homestead on the community property or the husband's separate property without the consent of the other spouse. ${ }^{.0}$ While the wife could declare a homestead on the husband's separate property without his consent, the husband could not, under section 1239 of the Civil Code, declare a homestead on the separate property of the wife without her consent.91 Prior to 1961 California real property purchased by a former nondomiciliary wife with funds which would be her separate property under the laws of her former domicile was classified as "California separate property" for declaration of homestead purposes. After 1961, if the funds used to purchase this real property in Califorma would have been community property had the wife acquired them in California, the realty would be considered quasi-community property under section 1237.5 of the Civil Code subject to a declaration of homestead by her husband without her consent under section 1238 . In other words, after 1961 what would before that time have been treated as the wife's separate property was to be treated as community property, from the time of change of domicile, for declaration of homestead purposes.

Under section 1242 of the Civil Code both spouses must join in the conveyance or encumbrance of the homestead. After 1961 a husband may therefore keep his wife from alienating her separate real property without his consent by declaring a homestead on it. ${ }^{92}$ Furthermore, if a homestead is declared on this realty and there should later be a divorce action in which the husband is the prevailing party, under the 1961

90 See 3 CaLIfornta Law Revision Comm'n, Reports, Recompmendations \& Studies, I-1, I-9-I-10 (1961); Marsh, supra note 38, at I-31-I-32. See also Cax. Crv. Code \$\$ 1237, 1240-41, 1261, 1269. On declared homesteads generally, see Haskins, Homestead Exemptions, 63 HaRv. L. REv. 1289 (1950).

91 This is still the law with respect to the wife's separate property, but after 1961 the term "separate property" as used in $\& 1239$ of the Civil Code includes only what would be considered the wife's separate property had it been acquired in California. See note 89 supra.

92 This statement assumes that the real property is of the type required under $\S 1237$ of the Civil Code. The requirement under $\& 1237$ that the homestead shall consist of the dwelling house plus the outbuildings and the land on which the structures are situated is to be biberally construed in the declarant's favor. In re Stering, 20 F. Supp. 924 (S.D. Cal. 1937); Quakenbush v. Reed, 102 Cal. 493, 37 Pac. 755 (1894). 
amendment to section 146 of the Civil Code this realty may go entirely to the husband.93

The former nondomiciliary wife will be able to argue that the homestead sections of the quasi-community property legislation diminish her property rights merely upon a change of domicile. Her husband may at any time after change of domicile restrict her right to ahenate her real property by declaring a homestead on it without her consent. ${ }^{94}$ Therefore, once she is a California domiciliary, she will no longer be able to invest funds she brings from her former common law domicile in realty without giving up her otherwise unconditional power to freely dispose of her property. This right of the husband, unlike the right of the nonacquirimg spouse to take part of the quasi-community property after dissolution of the marriage under section 146, vests immediately upon change of domicile. In other words, there is no legal action unconnected with the spouses' change of domicile, such as a divorce suit, which is a condition precedent to the husband's acquirmg the right to declare a homestead on his wife's realty and thereby decrease the rights of ownership which she would have under the law of her former domicile.

It is not only the declaration of the homestead by the husband which diminishes the wife's rights. His declaration perfects his rights and confirms the diminution in the wife's property rights which she suffers as soon as her husband acquires the right to restrict her powers of free alienation by declaring a homestead on any real property she may acquire. The right of a husband to declare a homestead is therefore analogous, not to the rights the nonacquiring spouse may obtain after dissolution of the marriage under section 146 of the Civil Code, but to the rights the nonacquiring spouse would have under section 201.5 of the Probate Code if Paley v. Bank of America ${ }^{95}$ had not demied the constitutionahty of an attempted construction of that section which would have given the nonacquiring spouse testamentary disposition over onehalf the quasi-community property. In the latter case, the acquirmg

93 "If a homestead has been selected from the community property or the quasi-conlnunity property, it may be assigned to the party to whon the divorce or decree of separate maintenance is granted ...." CAL. CIv. CODE \& 146 (c).

94 The restriction of a property owner's power of alienation constitutes an unconstitutional deprivation of a vested right. Roberts v. Wehmeyer, $191 \mathrm{Cal}$. 601, 218 Pac. 22 (1923); Comment, 12 CAIIF. L. REv. 124, 125 (1924). As a general rule, the rationale underlying Roberts has been substantially vitiated. See Shelley v. Kraener, 334 U.S. 1 (1948); Hurd v. Hodge, 334 U.S. 24 (1948); Village of Euclid v. Ambler Realty Co., 212 U.S. 365 (1926).

95 159 Cal. App. 2d 500, 324 P.2d 35 (1958); see note 32 supra. 
spouse would have lost, upon a change of domicile, the right to have complete testamentary disposition over his common law property. The loss of the right occurs not only if and when the nonacquiring spouse chooses to exercise the newly acquired testamentary power, but as soon as the spouses become California domiciliaries ${ }^{20}$ and the nonacquiring spouse acquires the right to exercise this power.

The wife's argument will therefore be that the quasi-community property homestead legislation is precisely the same type as that held unconstitutional by Thornton and distinguished in Addison from the divorce sections of the quasi-community property legislation. ${ }^{07}$ The argument in Thornton that such legislation constitutes an abridgement of the privileges and immunities clause of the fourteenth amendment was not disturbed in Addison. ${ }^{98}$ Unless it is overruled in a subsequent case, the constitutionality of section 1237.5 and the 1961 amendment to section 1238 of the Civil Code will be denied.

\section{B. The Possibility of Defeating Section 146}

In addition to raising serious doubts as to the constitutionality of the homestead sections of the quasi-community property legislation, Addison's failure to overrule the entire constitutional theory underlying Thornton threatens the successful implementation of the purpose behind the 1961 amendment to section 146 of the Civil Code. Under that amendment the court is to dispose of the quasi-community property upon dissolution of the inarriage in the same way that it would dispose of community property.

Addison holds that, unlike the 1917 amendment to section 164 held unconstitutional by Thornton, the 1961 amendment to section 146 neither applies inerely on a change of domicile nor affects the balance of marital property rights existing between husband and wife until their marital relationship is legally altered..$^{90}$ Unless, however, the concept of quasicommunity property is constitutionally applicable prior to the time $A d$ dison says it applies, a former nondomiciliary husband, anticipating a divorce or separate maintenance action, may be able to defeat his wife's rights under section 146.

${ }^{96}$ It should be noted that there is no requirement of domicile in any portion of the quasi-community property legislation. Addison appears to read this requirement into the divorce sections. See note 69 supra.

07 See notes 66-69 supra and accompanying text.

98 The loss of this right by the wife upon a change of domicile is a necessary concomitant of the establishment of a unitary (tripartite) marital property system which is achieved by the 1961 quasi-community property legislation and the upholding of its constitutionality, at least in part, in Addison. See text accompanying note 124 infra.

9062 Cal. 2d at 566, 399 P.2d at 901-02, 43 Cal. Rptr. at 101-02. 
There are two ways the former nondomiciliary husband may be able to avoid section 146 . He can invest his common law funds in realty outside of California since only real property in California is covered by section $140.5 .^{100}$ Or the husband can divest himself of title to his personal property by trust or gift arrangement, since his wife has no power to void a nonconsented-to transfer of common law marital property for which her husband did not receive valuable consideration as she would lave under section 172 of the Civil Code were it community property.

There are two possible solutions to the evasion problem created by the foreign realty exception. The first solution is to expand the definition of quasi-community property so that it contains no geographical limitation. The argument in support of expansion rests on the proposition that the interest of the domiciliary state "in the matrimonial property of the parties is substantial upon the dissolution of the marriage relationship." ${ }^{101}$ Since it is the well-being of the spouses, rather than the disposition of the property itself, after the dissolution of the marriage relationslip that is the real matter of legitimate state concern, ${ }^{102}$ the geographical limitation in section 140.5 is not only unnecessary, but is an obstacle to the successful implementation of its underlying purpose.

This solution is, however, in direct conflict with the traditional jurisdictional principle that the courts of one state cannot directly affect title to land in another state. ${ }^{103}$ Under this principle it has been held that a Nevada divorce decree declaring the noncommunity nature of California real property was subject to collateral attack in California by the

100 See note 2 supra.

101 Addison v. Addison, 62 Cal. 2d 558, 567, 399 P.2d 897, 902, 43 Cal. Rptr. 97, 102 (1965).

102 Schreter, supra note 53, at 238.

103 Fall v. Eastin, 215 U.S. 1 (1909); Commissioner v. Skaggs, 122 F.2d 721 (1941). There has been constant severe criticism of the doctrine of Fall $v$. Eastin. According to Professor Ehrenzweig, there has been "nearly unanimous opposition of legal writers to this dogma." Enrenzweig, Confuicr of Laws $\$ 58$, at 209 n.2 (1962). See generally Currie, Full Faith and Credit to Foreign Land Decrees, 21 U. CEI. L. REv. 620 (1954); Schwartz, Fall v. Eastin Revisited; Extraterritorial Effect of Foreign Land Decrees, 54 Dick. L. REv. 293 (1950). "[I]s it not clear that the California court, having two California domiciliaries before it in a divorce proceeding, can and should enter whatever decree for division of the marital property that is called for by California law and policy, irrespective of the law of [the situs state]? . . . [I]n the recent case of Rozan v. Rozan Justice Traynor, for a unanimous court, held that real estate in Nortl Dakota purchased witl coniniunity funds was community property, subject to division by the divorce decree, without making any reference to the law of North Dakota. No such reference is necessary, [Fall v. Eastin and] the Restatement to the contrary notwithstanding." Currie, Justice Traynor and the Confict of Laws, 13 Stan. L. Rev. 719, 743-44 (1961). See also Schreter, supra note 53, at 234. For criticisn of the lex situs doctrine generally, see EHRENzwEIG, op. cit. supra at $\S 232$, at $607-12$. 
spouse claiming a cominunity interest in the property. ${ }^{104}$ Although the court granting the divorce had jurisdiction over both parties to the action, it lacked jurisdiction to render a judgment determinative of title or rights in property outside its boundaries. ${ }^{105}$ While the cominentators are nearly unaninous in their condemnation of the traditional lex situs doctrine, ${ }^{106}$ the courts have merely developed hmitations upon it. Continued adherence to this doctrine prevents a court in a divorce proceeding from basing a decree for division of the marital property solely on what should be the governing consideration: the law and policy of the forum state. $^{107}$ This has been recently recogmized by the Cabifornia court in Rozan v. Rozan, ${ }^{108}$ which represents a departure from the lex situs dogma.

The second solution to the evasion of the section 146 problem created by the foreign realty exception in section 140.5 defining quasi-cominunity property-adaptation of the community property "tracing" doctrine to foreign realty purchased with quasi-coinnumity funds-is not dependent upon, as is the first solution, the immediate overruling of the jurisdictional doctrine of the lex situs. Instead, it is based on a limitation upon the doctrine. Althougl a court lacks jurisdiction to render a judgment which has a direct effect on real property in a foreign state, if the court has personal jurisdiction over the parties, it can adjudicate their rights in the property and order them to execute conveyances of the property which are necessary for a complete disposition of the case. ${ }^{109}$ Moreover, such an adjudication is to be accorded full faith and credit in the situs state regardless of whether the decree orders execution of a conveyance. ${ }^{110}$ Althougl such a decree cannot in itself change or determine title, and while a subsequent action for that purpose must be brought in the situs

104 Taylor v. Taylor, 192 Cal. 71, 218 Pac. 756 (1923).

105 See Wrtrin, 1 CaLIFornia Procedure, Jurisdiction $\S \S 54,90$ (1954).

106 See note 103 supra.

107 Currie, Justice Traynor and the Conflict of Laws, 13 STAN. L. REv. 719, 743-44 (1961).

10849 Cal. 2d 322, 317 P.2d 11 (1957). "There is no sound reason for denying a decree of a court of equity the same full faith and credit accorded any other kind of judgment. 'Without exception, the courts recognize the validity of a deed executed under the compulsion of a foreign decree. . . . Recognition of the deed necessarily involves acceptance of the decree. Whatever intrusion on the state's exclusive control is implied in the recognition of the decree is accomplished through the recognition of the deed. A policy so easily evaded, so dependent on the success of the defendant in eluding the enforcement process of the foreign court, is a formal, lifeless thing, and the truth must be that foreign judicial proceedings of this type pose no real threat to the legitimate interest of the situs state.' (Currie, [supra note 103, at 628-29] . . .)." Id. at 331, 317 P.2d at 16 .

109 Rozan v. Rozan, 49 Cal. 2d 322, 317 P.2d 11 (1957); Tomaier v. Tomaier, 23 Cal. 2d 754, 146 P.2d 905 (1944). See also Currie, supra note 107, at 743-44.

110 Rozan v. Rozan, supra note 109. 
state, an adjudication of the rights of the parties to the divorce action in the property is res judicata in the subsequent action. ${ }^{111}$

A general rule of marital property law now accepted by the great majority of states is that "the character of the funds or other property exchanged for land, and not [the character of the land as determined by] the law of the situs, determines the marital-property characteristics of an immovable acquired by purchase in a nondomiciliary jurisdiction."112 Therefore, if a Cahifornia domiciliary invests community funds in foreign realty, the realty is treated as community property in a subsequent divorce action. If the court granting the divorce has personal jurisdiction over both parties who claim a right in the foreign realty, the court can adjudicate their respective rights and either order one party to execute a conveyance of that part of the property to which the other is entitled, or issue a decree stating which party is entitled to the property that is res judicata and to be given full faith and credit in any subsequent action brought $\mathrm{m}$ the situs state to determine title. ${ }^{113}$

The purpose of the 1961 amendment to section 146 was to have quasicommunity property treated as community rather than separate property on divorce. Therefore, the court adjudicating the divorce should be able to adjudicate the parties' rights in foreign realty purchased with quasicommunity funds in the same way it would had the funds been community property. The question is whether this is possible given Addison's retention of the third constitutional theory underlying Thornton.

If a court can adjudicate the parties' rights in foreign realty purchased with quasi-community funds under section 146 , so that a former nondomiciliary cannot defeat his spouse's rights under section 146 by making such an investment, it is because the concept of quasi-community property is constitutionally applicable prior to the time Addison says it applies. The court will have to consider the character of all the property the former nondomiciliaries brought to California from the time of change of domicile. From that time on, any property which would have been community property had it been acquired in California will be subject to disposition under section 146 if the spouses subsequently divorce

111 Barber v. Barber, 51 Cal. 2d 244, 331 P.2d 628 (1958). "The rule of the Rozan case, however, cannot properly be applied to a judgment which may be collaterally attacked in the rendering state on the ground that it is void for lack of jurisdiction." Id. at 247,331 P.2d at 631 .

112 Marsh, Marital Property in Confutct of Laws 190 (1952). See also Ehrenzweig, op. cit. supra note 103 , at $\S 245$, at $649-50$.

113 Barber v. Barber, 51 Cal. 2d 244, 331 P.2d 628 (1958); Rozan v. Rozan, 49 Cal. 2d 322, 317 P.2d 11 (1957). See also Durfee v. Duke, 375 U.S. 106, 115 (1963): The "rule of jurisdictional finality" applies to cases involving real property. 
in California, regardless of low or where that property is transformed. Admittedly, this is a "hindsight" reclassification of the marital property at the time of divorce. But if the concept of quasi-community property applies only to property which at the time of the divorce is covered by section $140.5{ }^{114}$ then the acquiring spouse will be able to defeat his spouse's rights under section 146 by investing in foreign realty. The rule of Thornton that marital property rights cannot be reclassified during marriage merely on a change of doinicile must therefore be completely overruled, or only that property which at the time of divorce is covered by section 140.5 can be disposed of as quasi-community property. ${ }^{115}$

The possible solutions to the second way in which the former nondoiniciliary husband may avoid section 146 also depend upon a complete overruling of the constitutional theory underlying Thornton. If the purpose of section 146 is not to be defeated, the former nondomiciliary wife must be given the right to avoid nonconsented-to gifts with respect to all the couple's common law marital property which would be classified as quasi-community property on divorce, as soon as the spouses move to California. This is similar to those rights in community property given by sections 172 and $172 \mathrm{a}$ of the Civil Code. ${ }^{116}$

If the husband makes a nonconsented-to gift of community property and the wife claims in a subsequent divorce action that she is entitled to part of that property under section 146, the court has the power to determine the community character of the property and award part of it to the wife even though it stands in the name of a third party. ${ }^{117}$ In

114 See note 2 supra.

$115 \mathrm{It}$ is arguable that the legislature, by explicitly omitting foreign realty from the definition of "quasi-community property" in $\$ 140.5$ of the Civil Code, manifested an intention not to apply the quasi-community property legislation to real property outside California. However, the 1961 amendments to the Civil Code also imposed a similar geographical limitation on the definition of commumity property in $\S 164$. This was probably the result of both a concern with the doctrine of Fall $\nu$. Eastin and a belief that the courts (1) would continue to apply the "tracing" doctrine to foreign realty for purposes of disposition of the community property on divorce, and (2) would similarly apply the tracing doctrine to cases involving quasi-community real property in accordance with the legislative purpose of having quasi-commumity property treated as community property on divorce. See Schreter (now Kay), "Quasi-Community Property" in the Conflict of Laws, 50 CALIF. L. REv. 206, 238 (1962). See also note 103 supra.

116 Under $\S 172$ of the Civil Code the nonconsenting wife may void a gift of community personalty in its entirety during the life of her husband and recover an undivided one-half of such property in an action brought against the donce after the death of her husband. Ballinger v. Ballinger, 9 Cal. 2d 330, 70 P.2d 629 (1937); Laheny v. Laheny, 208 Cal. 323, 281 Pac. 67 (1929); Dargie v. Patterson, 176 Cal. 714, 169 Pac. 360 (1917). Under $\$ 172 \mathrm{a}$ the wife has a similar right with respect to conveyances of community realty in which she did not join. Trimble v. Trimble, 219 Cal. 340, 26 P.2d 477 (1933); Yearout v. American Pipe \& Steel Corp., 74 Cal. App. 2d 139, 168 P.2d 174 (1946); Jack v. Wong Shee, 33 Cal. App. 2d 402, 92 P.2d 449 (1939).

117 Elms v. Elms, 4 Cal. 2d 681, 52 P.2d 223 (1935). 
order to prevent the former nondomiciliary husband from avoiding section 146 by making nonconsented-to gratuitous transfers of his common law property which would be quasi-community property on divorce, either (1) the wife must be given the power to void such transfers during the marriage by amending sections 172 and $172 \mathrm{a}$ to bring quasi-community property within their scope; or (2) the wife must be allowed to claim in a divorce action that property standing in the name of a third party is quasi-community property and that she is entitled to her share under section 146 because the husband disposed of this property for an inadequate consideration without her consent.

To give the former nondomiciliary wife either of these rights it is necessary to argue that application of the concept of quasi-community property during marriage and merely on a change of domicile is not unconstitutional. The first solution, which is to amend sections 172 and 172a to include quasi-community property, involves an alteration of marital property rights as soon as the spouses become Cahfornia domiciliaries, for from that time on the wife would be able to invalidate nonconsented-to gratuitous dispositions of the quasi-colnmunity property by her husband. The second solution outhined above is perhaps less drastic in that it gives the wife such a right only if the spouses seek a divorce. It too, however, involves a reclassification of marital property prior to the time Addison holds that the concept of quasi-community property apphes. Allowing the wife in a divorce action to claim a share in her husband's common law property which he transferred to a third party some time after the couple's change of domicile and before the divorce, constitutes a restriction on the husband's right to freely dispose of his property during inarriage merely because of a change of domicile, and imphes a reclassification of the property from coinmon law separate property into quasi-community property much before the time sanctioned. by Addison.

Althougl the second solution may appear to be closer to the limited purposes of the quasi-community property legislation than the first solution, it is, practically speaking, an unrealistic alternative. The transferee of the husband's common law property would not be able to rely on the gift being permanently vahid. The possibility of one-half the gift being voided would depend upon the likelihood of the transferor's spouse bringing a divorce action and claiming an interest in the transferred property under section 146 . Too much uncertainty would therefore be engendered by this solution.

As a means of protecting the nonacquiring spouse's rights under section 146, this second solution would be at best unrehiable. Whether the right to recover one-half of nonconsented-to gifts of quasi-community 
property on divorce will constitute meaningful protection in a particular case would depend upon the treatment of the property by the donee. Where the amount of the gifts and the identity of the donee are known, and the transferred property can be readily reached, this means of protection may be sufficient. However, it offers no protection in those cases where the donee may have dissipated the property, or where the donee or the property may be difficult to locate or bring under the jurisdiction of the court. ${ }^{118}$ To protect the nonacquiring spouse's rights under section 146, sections 172 and 172 (a) of the Civil Code should therefore be extended to include quasi-community property. This would both (1) give the former nondomiciliary nonacquiring spouse the same protection of her quasi-community property rights which was given the Califorma nonacquiring spouse's community rights in $1891,{ }^{110}$ and (2) limit the acquiring spouse's right to freely alienate his common law property durmg marriage and on a change of domicile. Since such a reclassification of rights is necessary to prevent avoidance of section 146 , the successful implementation of the purpose underlying the 1961 amendment to this

118 In Fields v. Michael, 91 Cal. App. 2d 443, 205 P.2d 402 (1949), the wife's rights under $\$ 172$ of the Civil Code were extended to allow recovery from the personal representative of her deceased husband of the value of her share of the commumity property wrongfully given away by the husband during his lifetime where suit against the donces would be impossible or ineffective. Prior to this time the wife had only two ways to enforce her rights under § 172: suit against the donee during the life of her busband to recover the entire nonconsented-to gift of community property, and suit against the donee after the death of her husband to recover her one-half interest in the nonconsented-to gift of conmunity property. See note 116 supra. The rationale of the court in extending the wife's remedies was: "[W]here recourse against the donees would be ineffective to give relicf, as in the present instance, a denial of the alternative remedy [i.e., suit against the husband's estate] would ... amount to a concession that the law is powerless to accord to the wife's community interest the full protection which section 172 was evidently designed to ensure." $91 \mathrm{Cal}$. App. 2d at 448-49, 205 P.2d at 406.

The argunient here is that the same rationale supports extension of the wife's quasicommunity property rights to prevent defeat of those rights altogether. Moreover, the court in Fields denies that $\$ 172$ cannot apply to conmunity assets acquired before 1927 when the wife had less than a "present, existing and equal" interest in the community property. Prior to 1927 the wife had more than the interest of "a nuere heir," and § 172 was enacted to insure protection of that interest. $91 \mathrm{Cal}$. App. 2d at 449, 205 P.2d at 406. By analogy, the wife's interest in the quasi-community property is more than that of an heir after the 1961 legislation. She not only has the right to one-half the quasi-community property on the death of her husband under $\$ 201.5$ of the Probate Code, but also the right to a division of the quasi-conmmunity property under $\S 146$ of the Civil Code on divorce or separate maintenance. The right to bring suit during marriage to void a nonconsented-to gift should therefore be extended to quasi-comnunity property to insure full protection of the nonacquiring spouse's interests.

119 In 1891 a proviso prohibiting a gift of conmunity property or a conveyance without valuable consideration unless the wife consents in writing was added to $\$ 172$ of the Civil Code. Cal. Stats. ch. 220, at 425 (1891); see note 82 supra. 
section requires that the remaining constitutional basis of Thornton retained by Addison be overruled. ${ }^{120}$

\section{CONCLUSION}

Addison sharply limits the two general conflict of laws principles which have governed Califorma marital property law for more than half a century. It is no longer axiomatic that marital property rights must be governed by the laws of the domicile of acquisition and that laws changing the balance of inter vivos marital property riglts existing between a husband and wife can be applied prospectively only.

Though the Addison court did not find it necessary to expressly overrule Spreckels or Thornton, Spreckels has for all practical purposes been prospectively overruled. With the emasculation of the Spreckels vested rights axiom, two-thirds of the constitutional theory underlying Thornton has also been overruled. The remaining one-third, however, constitutes a threat to the effective implementation of section 146 of the Civil Code and the constitutionality of section 1238 of the Civil Code.

Whether the supposed constitutional rule that marital property riglits cannot be changed merely on a change of domicile during the continuance of the marriage stands after Addison is questionable. The rationale of Addison is the interest of the state in effectuating the purpose of the 1961 quasi-community property legislation: to give the spouses the protection they would have had under the community property system had they acquired the property in California as a substitute for the protection they would have had if they had remained in their former common law domicile and souglit a divorce there. Since the state has a legitimate interest in regulating the inter vivos marital property riglts of spouses, the application of the concept of quasi-comnunity property during marriage merely on a change of domicile can be upheld as constitutional under the balancing of interests approach of Addison. If the concept of quasicommunity property cannot constitutionally be applied as soon as the spouses become California domiciliaries, (1) the constitutionality of the quasi-community property homestead legislation is very doubtful and (2) the possibility of defeating section 146 is great, since the court will be unable (a) to apply the tracing rule to real property outside Califoruia purchased with quasi-community funds and (b) to allow the wife to successfully claim a share in quasi-conmunity property transferred to a third party for an inadequate consideration without her consent. It cannot be the case, therefore, that the legislation involved in Addison is constitutional only if it is distinguishable from that involved in Thornton

120 See text accompanying notes $64-75,87$ supra. 
in terms of its time of application and effect on the spouses' marital property rights during marriage.

The quasi-community property legislation was, however, distinguished by Addison from the legislation involved in Thornton in one other way. The 1917 amendment to section 164 of the Civil Code purported to reclassify common law marital property into community property for all purposes. ${ }^{121}$ The quasi-community property legislation treats common law marital property as community property only on some occasionsthose in which the state has a legitimate concern. ${ }^{122}$ Addison may therefore be read as limiting Thornton to legislation which would seek indiscriminately to bring the property of former nondomiciliaries under the community property laws for any and all purposes without regard to which incidents of marital property the state has a legitimate interest in regulating.

It is necessary to eliminate this final vestige of Thornton only if one believes that the logical and desirable end of the quasi-community property legislation is to establish a unitary marital property system which has a dichotomous classificatory schema. The balancing of interests rationale which the court uses in Addison denies the desirability of a dichotomous marital property system in California for all property wherever acquired and recognizes the hybrid nature of common law property. ${ }^{123}$ The constitutionality of the divorce sections of the quasicommunity property legislation is upheld, not because marital property which would be community property had it been acquired in California should always be treated by the California courts as if it had been acquired in Cahifornia, but because the state's interest in protecting the former nondomiciliary wife on divorce is served better by treating her husband's common law property as community property rather than as California separate property. This approach implies that where the state does not have a similar legitimate interest in regulating the marital property rights of former nondomiciliaries, common law marital property should be treated as the separate property of the acquiring spouse rather than as community property. In other words, since common law property is different fron both California separate property and community property, but has traditionally been treated as California separate property to protect the rights of the acquirmg spouse, California is justified in treating this property as community property only when the state's interest in regulating former nondomiciliaries' rights in common law

121 See note 68 supra and accompanying text.

122 See notes 55-56 supra and accompanying text.

${ }^{123}$ See note 22 supra and accompanying text. 
marital property outweighs the traditionally recognized interests of the acquiring spouse.

This does not mean, however, that the quasi-community property legislation is not the beginning of the creation of a unitary marital property system in California. ${ }^{124}$ On the contrary, with the enactment of the quasi-community property legislation and the court's use of a balancing of interests rationale to defeat the axiomatic nature of the Spreckels and Thornton rules in Addison, California has achieved a unitary system of inarital property based on a tripartite, rather than a dichotomous, classificatory schema: All marital property owned by California domiciliaries, whenever or wherever acquired, comes under the existing laws governing either separate, quasi-cominunity, or community property.

Barbara Brudno Gardner

124 See note 10 supra. 